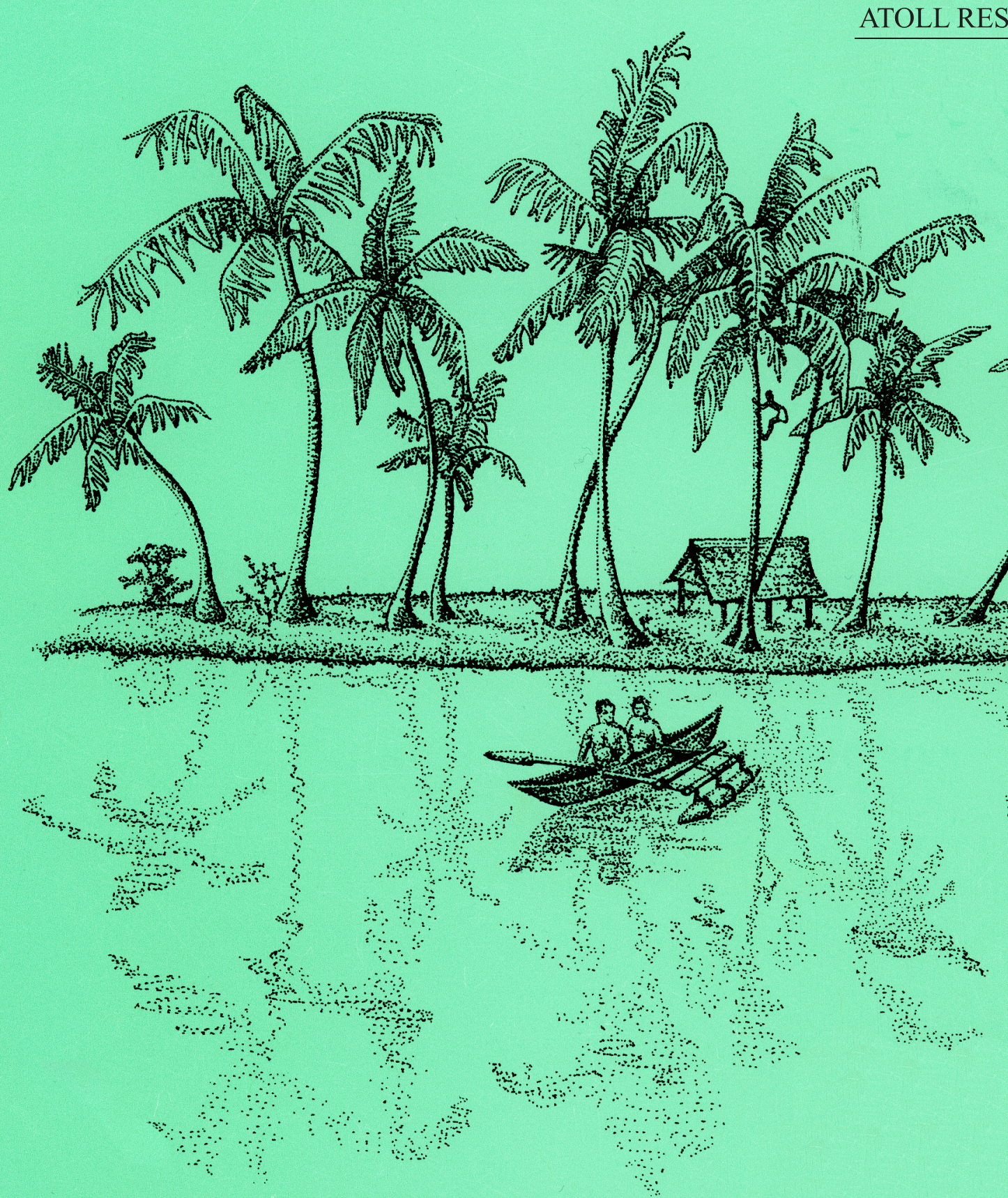




\section{SAILING THROUGH TIME: A HISTORICAL EXAMINATION OF THE EXPLORATIONS AND EXPEDITIONS OF THE PAPAHĀNAUMOKUĀKEA MARINE NATIONAL MONUMENT}

Carlie S. Wiener and Daniel Wagner

Atoll Research Bulletin No. 594 12 November 2013

Smithsonian Institution

Scholarly Press 
All statements made in papers published in the Atoll Research Bulletin are the sole responsibility of the authors and do not necessarily represent the views of the Smithsonian Institution or of the editors of the Bulletin. Articles submitted for publication in the Atoll Research Bulletin should be original papers and must be made available by authors for open access publication. Manuscripts should be consistent with the "Author Formatting Guidelines for Publication in the Atoll Research Bulletin." All submissions to the Bulletin are peer reviewed and, after revision, are evaluated prior to acceptance and publication through the publisher's open access portal, Open SI (http://opensi.si.edu).

Published by SMITHSONIAN INSTITUTION SCHOLARLY PRESS

P.O. Box 37012, MRC 957

Washington, D.C. 20013-7012

www.scholarlypress.si.edu

The rights to all text and images in this publication are owned either by the contributing authors or third parties. Fair use of materials is permitted for personal, educational, or noncommercial purposes. Users must cite author and source of content, must not alter or modify the content, and must comply with all other terms or restrictions that may be applicable. Users are responsible for securing permission from a rights holder for any other use.

ISSN: 0077-5630 (online) 


\title{
SAILING THROUGH TIME: A HISTORICAL EXAMINATION OF THE EXPLORATIONS AND EXPEDITIONS OF THE PAPAHĀNAUMOKUĀKEA MARINE NATIONAL MONUMENT
}

\author{
BY \\ CARLIE S. WIENER ${ }^{1}$ and DANIEL WAGNER ${ }^{2}$
}

\begin{abstract}
Many decades of exploration and documentation of the Northwestern Hawaiian Islands (NWHI) have shown dynamic and pristine ecosystems that have been a source of cultural, economic and scientific wealth. Recent calls for large-scale and archipelagic-wide ecosystem management build upon this history, emphasizing holistic and integrated science and institutional collaboration. Given the successful experiences of the Papahānaumokuākea Marine National Monument (PMNM), the Hawaiian Islands serve as a commendable example of the value of scientific exploration in support of resource management. Past activities ranging from exploration, voyaging, monitoring and protection are all essential to these initiatives, contributing to an improved global understanding of ocean systems and environmental changes. This article draws on local knowledge, histories and scientific expeditions to reflect on past exploration and its importance to what we now know about the NWHI. The integration of previous expeditions and science initiatives is demonstrated through the increasingly successful ecosystem-based management of PMNM and support for archipelagic-wide marine managed areas. Reflections on how these histories influence present day research questions and future management directions are also discussed.
\end{abstract}

\section{INTRODUCTION}

Approximately 4,000 km from the coasts of California and Japan in the central North Pacific lies one of the world's most remote island chains (Figure 1), harboring one of the last apex predator dominated ecosystems on Earth. Large fish such as sharks, trevally and Hawaiian grouper are abundant in these waters that otherwise are rarely seen in large numbers elsewhere (Friedlander and Martini 2002; Friedlander et al., 2005; Grigg et al., 2008). The Northwestern Hawaiian Islands (NWHI) are a series of seamounts, banks, shoals, reefs, atolls and islands spanning over $362,000 \mathrm{~km}^{2}$ (Figure 1) that represent a substantial proportion of the healthy coral reef ecosystems in the United States (Friedlander et al., 2005; Grigg et al., 2008; Rooney et al., 2008). Twenty five percent of over 7,000 known marine species found in this region are endemic, found nowhere else on the planet, including 19 threatened and endangered plant and animal species (Friedlander et al., 2005). These islands also exemplify clear sequential, volcanic evolution, beginning with the oldest, Kure Atoll with an approximate age of 30 million years, and expanding to newest and still growing Hawai'i Island (Grigg 1988, 1997; Rooney et al., 2008). Although these islands attribute their evolution to the movement of the Pacific Tectonic Plate over the Hawaiian hotspot (Grigg 1988, 1997; Rooney et al., 2008), their development and discovery is one that goes much deeper than plate tectonics.

\footnotetext{
${ }^{1}$ Hawai‘i Institute of Marine Biology, 46-007 Lilipuna Road, Kāne‘ohe, HI 96744, U.S.A. Email: cwiener@hawaii.edu.

${ }^{2}$ NOAA Papahānaumokuākea Marine National Monument, 6600 Kalaniana‘ole Highway, Suite 300, Honolulu, HI 96825, U.S.A. Email: Daniel.Wagner@noaa.gov.
} 


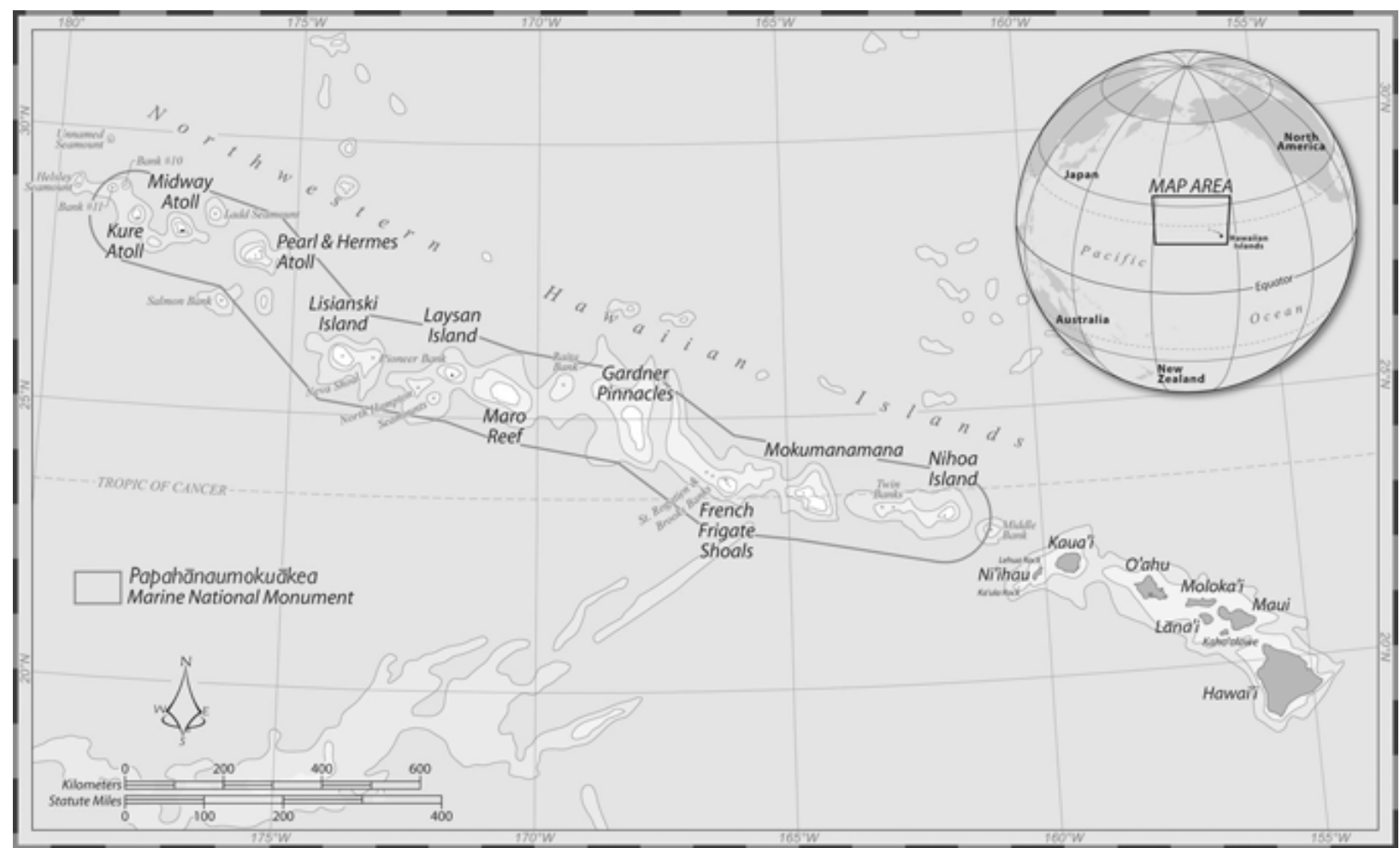

Figure 1. Map of the Hawaiian Archipelago outlining both the Main Hawaiian Islands and Northwestern Hawaiian Islands, the latter of which now encompass the Papahānaumokuākea Marine National Monument.

Due to the unique biological and cultural features of the NWHI, this region has undergone a long history of protection and management (Bryan 1978; Yamase 1982; Shallenberger 2006; Keller et al., 2009). Early efforts towards conservation in this region began when President Theodore Roosevelt established the Hawaiian Islands Reservation in 1909. In 1940, President Franklin Roosevelt changed the name of the reserve to the Hawaiian Islands National Wildlife Refuge and increased the protection of this area. Additional protection was offered in 1988 through joint efforts by the U.S. Fish and Wildlife Service and the Navy that created an overlay of the National Wildlife Refuge at Midway Atoll. This legacy of protection continued through the new millennium, when President William Clinton signed executive orders in 2000 that created the NWHI Coral Reef Ecosystem Reserve. In 2005, Hawai'i Governor Linda Lingle signed regulations that established the NWHI State Marine Refuge, covering all of the state waters of the region (out to three nautical miles from shores with the exception of Midway Atoll). Following these developments, the United States considered designating a substantial portion of the federal waters of the NWHI as a national marine sanctuary; however, the National Oceanic and Atmospheric

Administration (NOAA) declared this coral reef ecosystem as a marine area of special significance under the National Marine Sanctuaries Act (Ward 2010; Rieser 2012). Following this decision, President George W. Bush determined that more immediate protection was warranted. In 2006, Bush used the Antiquities Act to create the Papahānaumokuākea Marine National Monument (PMNM), thereby affording the region the highest level of protection possible under United States law (Ward 2010; Rieser 2012).

Dealing with expansive ecosystems like the NWHI requires adaptive management that speaks to the multitude of issues associated with complex, remote and large systems (Wiener et al., 2011). To address this, PMNM managers have implemented an ecosystem-based management approach (PMNM 2008; Keller et al., 2009). This form of management has been broadly accepted in policy, conservation and science, as a crucial tool for the effective conservation and preservation of a multitude of diverse natural resources (Tissot et al., 2009; Wiener et al., 2011). Moving from a single species to an ecosystem-based approach requires a concerted effort towards the integration of science into management. Ecosystem- 
based management relies heavily on scientific inquiry for an understanding of the status and changes related to the managed environments (Wiener et al., 2011). This is exemplified by the PMNM Monument Management Plan, which explicitly supports a scientific initiative to support, promote and coordinate research, in order to increase the understanding of the NWHI and thereby improve management efforts (PMNM 2008). The NWHI represent a biologically diverse environment that is relatively free of anthropogenic impacts (Friedlander et al., 2005; Selkoe et al., 2008; Selkoe et al., 2009). This makes the NWHI an ideal site to conduct scientific studies on comparatively pristine ecosystems, thus serving as one of only a few natural laboratories and sentinel sites for human impact on the globe (Wagner et al., 2013).

The NWHI have been an important source of cultural and scientific wealth, and for this reason were distinguished globally through World Heritage designation in 2010 for both its natural and cultural values, representing the only site of this kind in the United States (Jokilehto 2011). Not only is it a place of remarkable natural beauty, but the Monument also constitutes a collection of places of great cultural and spiritual significance, also known as wahi pana in the native Hawaiian language (Emory 1928; Bryan 1978; Cleghorn 1988). This article aims to investigate the many decades of exploration of the NWHI, by demonstrating the dynamic changes of use and consideration for these pristine environments. Recent calls for large-scale and archipelagic-wide ecosystem management build upon this history, emphasizing holistic and integrated science and institutional collaboration. The history of research in the NWHI is traced through various phases of study including early voyages, resource exploration and extraction, modern scientific monitoring and present day research. Changing technology and management approaches are also considered as catalysts for shifting regimes in scientific exploration. Lastly, existing research partnerships that currently work to integrate science with the Monument management plans are discussed as a key to successful scientific exploration in the present day.

\section{EARLY VOYAGES}

Early on, native Hawaiians had profound insights into the natural history of the Hawaiian Islands. For instance, they knew that the island of Kaua'i was older than the other islands extending southward, as evidenced by the designation of Kaua'i as the first home to the Goddess Pele, who then moved southeastward island by island as its volcanoes became extinct, until she reached Hawai'i Island, where she is now believed to reside (Westervelt 1916; Bryan 1978; Grigg 2006). This intimate knowledge of their natural surroundings extended into daily practices including hunting, navigating and conservationbased management systems known in the native Hawaiian language as the ahupua á (Jokiel et al., 2011). This well-planed and resourceful way of management included the entire island system, spanning from the top of the mountains to the outer edges of coral reefs. The intertwined relationship between natural and cultural resources is the crux of the Hawaiian belief system (Jokiel et al., 2011).

In fact, the Hawaiian creation story, the kumulipo, begins with life evolving from the sea in the form of a single coral polyp, then extends to larger species, and eventually culminates on land with the birth of humans (Beckwith 1949). The coral as an important base of the ecosystem has remained unchanged and continues to be the root of many monitoring and assessment programs, not only for Hawaiians, but for Western scientists as well (PMNM 2008; Jokiel et al., 2011). The traditional ahupua a system has been gradually replaced with more Western-based management rooted in scientific research; but, recent initiatives have revisited original Hawaiian management approaches, blending both the wisdom of the past with present day science (PMNM 2008; Jokiel et al., 2011). This trend in history is best demonstrated by the changing exploration and management of the NWHI.

Native Hawaiians were well aware of the existence of the NWHI with evidence of voyaging to these islands as early as 1000 A.D. (Emory 1928; Bryan 1978; Cleghorn 1988). The significance of these islands as resting places for spirits and gods added to the importance of these geological landmarks. In fact, the first two islands in the NWHI chain, Nīhoa and Mokumanamana, were periodically inhabited between 1000 and 1700 A.D. (Emory 1928; Bryan 1978; Cleghorn 1988; Schultz et al., 2011). This is evidenced by a high abundance of artifacts including over 140 identified archaeological sites on these two islands alone, making them some of the densest scatters of prehistoric archaeological remains in Hawai'i 
(Emory 1928; Bryan 1978; Cleghorn 1988). As a result, both Nīhoa and Mokumanamana are listed on the National and State Registers of Historic Places. The lands of the NWHI have always been remote, and therefore not heavily accessed; however, throughout history this region has been essential to the economy, culture and politics of Hawai' $i$, as further evidenced by the formal annexation of several NWHI by the Hawaiian Monarchy in the $19^{\text {th }}$ century, including Nīhoa, Mokumanamana, French Frigate Shoals, Laysan, Lisianski and Kure (Yamase 1982). Furthermore, representatives of the Hawaiian Kingdom regularly visited these remote islands, with distinguished visits to the Island of Ninhoa by Queen Ka'ahumanu in 1822, King Kamehameha IV in 1857 and Princess Lili ‘uokalani in 1885 (Bryan 1978; Yamase 1982; Clapp et al., 1977).

In more modern times, traditional voyaging practices have reemerged primarily through the efforts of the Polynesian Voyaging Society (Finney 2003; Bell 2007). The rebuilt sailing canoe Hokule ' $a$ has become the cornerstone of the Hawaiian renaissance using traditional navigating sciences that utilize natural elements like the stars, winds and seas for way finding. Hokule a has made many voyages since its first trip to Tahiti in 1976, including to the Hawaiian Islands and the rest of the Pacific (Finney 2003; Bell 2007). In September 2003, the Hokule 'a sailed along an ancient route to the NWHI in order to examine the cultural and biological wonders of the region (Bell 2007). The important leg of this voyage culminated on the island of Ninoa, where cultural protocols were performed to set the stage for the rest of the voyage (Bell 2007). In 2004, Hokule 'a revisited the NWHI, traveling to the furthest atoll, Kure (Bell 2007). Prior to the reemergence of traditional sailing, human access to the NWHI has been primarily limited to exploration, resource use and preliminary research activities. Building on the past centuries of exploration, a review of resource expeditions is briefly presented below.

\section{RESOURCE EXPLORATION AND EXTRACTION}

The first Western scientific discovery of the Hawaiian Archipelago was during Captain James Cook's expedition that arrived in the Main Hawaiian Islands in 1778 (Grigg 2006). During the same year, Captain Colnett of the British vessel Prince of Wales became the first Westerner to discover the NWHI of Nihoa; however, a wealth of natural history knowledge had already been accumulated by native Hawaiians since their arrival on this island roughly 800 years earlier (Emory 1928; Bryan 1978; Cleghorn 1988; Rauzon 2001). It was during the late $19^{\text {th }}$ and early $20^{\text {th }}$ century that exploration of the remote NWHI became prominent. With a few exceptions, the majority of sailing at this point was routed in resource exploration and extraction. Numerous Western travelers navigated through the NWHI and made important observations about the natural history of this region, which were thoroughly documented in logbooks and journals (see Bryan 1978; Olson 1996). Both the U.S. Exploring Expedition and the British Challenger Expedition passed through the NWHI during the 1840s and 1870s, respectively (Dana 1846; Nares and Thomson 1895). These oceanographic excursions centered their sampling efforts on the Main Hawaiian Islands; however, limited surveys were also performed in the NWHI (Dana 1846; Nares and Thomson 1895; Olson and James 1994). The first dedicated scientific expeditions that sought to systematically characterize the natural resources of the NWHI were the Albatross Expedition of 1902 and the Tanager Expeditions of 1923 and 1924.

\section{Albatross Expedition}

As a result of declining fisheries off the continental United States, U.S. Congress provided funding to construct a research vessel that would seek to discover new fishing grounds in order to increase the supply of American food fish (Allard 1999). In 1882, the U.S. Fish Commission Steamer Albatross was launched in direct response to these developments. Measuring 234 feet in length, 27.5 feet in maximum beam width and displacing 1,074 tons, the Albatross was the world's first large deep-sea oceanographic research vessel (Allard 1999; Allard et al., 1999; Summers 1999). The steamer contained a freshwater distilling plant which allowed for prolonged deployments at sea, and was equipped with a pair of powerful dredging engines carrying over $8,000 \mathrm{~m}$ of steel rope, which allowed for the collection of 
samples to abyssal depths approaching 5,500 m (Allard 1999). Additionally, the Albatross was the first U.S. government vessel to be fully electrified, thus allowing it to conduct nighttime operations which were necessary to collect samples at the extreme depths of the deep sea. The Albatross would have a lustrous scientific career spanning close to 40 years that included voyages through many parts of the globe including the NWHI. In 1902 the Albatross sailed to the Hawaiian Islands where the ship collected deep-sea specimens via dredging and trawling in pursuance of investigations concerning fishes and fisheries of the archipelago (Gilbert 1903). The Albatross arrived in Honolulu on March 27, 1902 and surveyed Hawaiian waters through August 23, 1902 when the ship departed for San Francisco (Bowers 1903). During the five months the Albatross spend in Hawai' $i$, a total of 344 trawls or dredges were performed in Hawaiian waters, including numerous deep-sea collections in the vicinity of the NWHI of Nīhoa, Mokumanamana, French Frigate Shoals and Laysan to depths approaching 3,000 m (Bowers 1903; Gilbert 1903). In addition to collecting biological specimens, the Albatross performed depth soundings, made tidal observations, and measured the temperature, specific gravity and salinity of Hawaiian ocean waters (Bowers 1903). A great wealth of scientific discoveries resulted from these surveys, including the finding of hundreds of new species, which were published in numerous monographs focusing on various taxonomic groups. These monographs included descriptions of a myriad of Hawaiian marine species, most of which were only known from the Albatross collections at that time, including 227 species of shore fishes (Snyder 1904), 111 species of deep-sea fishes (Gilbert 1903), 91 species of scleractinian corals (Vaughan 1907; Cairns 1984), 75 species of octocorals (Nutting 1908; Bayer 1952; Bayer 1956), 49 species of hydroids (Nutting 1903), 52 species of polychaetes (Treadwell 1903), 27 species of sea cucumbers (Fisher 1907), 28 species of cephalopods (Berry 1912) and 3 species of nemertean worms (Coe 1903). The Albatross collections were in fact so prolific, that many of the specimens collected in Hawai'i still remain to be described to this day.

\section{Tanager Expeditions}

The next dedicated scientific voyages to the NWHI were two expeditions by the U.S. Navy ship Tanager in 1923 and 1924 (Bryan 1978; Olson 1996). The USS Tanager was a 188 feet long minesweeper with a 35 foot beam, which served in the North Sea during World War I (Olson 1996). Following the war, the Tanager was reassigned to the Pacific fleet and consequently operated out of Pearl Harbor between 1920 and 1941 (Olson 1996). In 1923, the U.S. Navy partnered with the Bureau of the Biological Survey (now the U.S. Fish and Wildlife Service) and the Bishop Museum to conduct a series of expeditions to the NWHI. The purposes of these expeditions were to (1) fulfill the Bureau of the Biological Survey's mandate to survey the Hawaiian Islands Bird Reservation established in the NWHI in 1909, (2) perform a thorough biological reconnaissance of the NWHI, (3) eliminate rabbits which had previously been introduced to Laysan in 1903 and were decimating the native vegetation and fauna, and (4) gather navigational data for military use by the U.S. Navy (Olsen 1996; Ely and Clapp 1973). The first Tanager Expedition was primarily a natural history survey of the NWHI, Johnston Atoll and Wake Island that took place between April and August of 1923. During this first Tanager expedition, numerous specimens of terrestrial and marine organisms were collected and brought back to the Bishop Museum in Honolulu for further study (Olson 1996). Additionally, this first expedition discovered numerous archaeological sites in the NWHI, and as a result, a second expedition was launched in 1924 to document archaeological artifacts on the NWHI of Nīhoa and Mokumanamana (Emory 1928; Olson 1996). Results

from the two Tanager Expeditions were published by the Bishop Museum in six separate papers that dealt with different findings on the various resources of the NWHI, including the region's marine invertebrates (Edmonson et al., 1925), fish species (Fowler and Ball 1925), insects (Bryan et al., 1926), flora (Christophersen and Caum 1931), geology (Palmer 1927), and archaeology (Emory 1928). Additionally, descriptions of many species collected and documented by the Tanager were published in later years, including accounts of 43 species of algae (Tsuda 1965), 37 species of birds (Olson 1996) and 13 species of bird lice (Thompson 1948). 


\section{Fisheries, Mining and Hunting}

The rich natural resources of the NWHI, although remote, were soon discovered by early expeditions that sought monetary gain from the region. This lead to a wave of collection missions exploiting ocean resources, including commercial harvesting of whales, seals, turtles, sharks, sea cucumbers and pearl oysters, as well as the available land resources, namely birds (Spennemann 1998; Shallenberger 2006; Duffy 2006). Laysan Island was one of the places most heavily affected, with a tremendous change in vegetation and birdlife (Lamoureux 1963; Ely and Clapp 1973). Mining for guano and the hunting of birds for their eggs and feathers took an enormous toll on the island ecosystem (Ely and Clapp 1973). Nearly a half million tons of guano were extracted from Laysan Island alone (Shallenberger 2006). Between 1842 and 1915, over 1.3 million seabirds were harvested at Laysan, Lisianski and Midway (Spennemann 1998; Shallenberger 2006; Duffy 2010). Additionally, rabbits which had been introduced to Laysan in 1903 were decimating the native vegetation and bird fauna (Butler and Unsinger 1963; Lamoureux 1963; Ely and Clapp 1973; Olson 1996; Athens et al., 2007; Duffy 2010). This in turn wreaked havoc on the native fauna and flora of Laysan, and by 1923 only four of the originally documented 27 species of plants, as well as only three of five land bird species, remained (Butler and Unsinger 1963; Lamoureux 1963; Ely and Clapp 1973; Clapp et al., 1996; Athens et al., 2007; Duffy 2010).

Birds were not the only species to be hit, hunting of the Hawaiian monk seal, overexploitation of various fishery species and the near extinction of the pearl oyster at Pearl and Hermes Atoll occurred near the beginning of the $20^{\text {th }}$ century (Keenan et al; 2006; Shallenberger 2006; Schultz et al., 2011). The monk seals were hit early on, and their populations quickly went from abundant to meager due to the hunting of thousands of seals for their meat, skins and oils (Schultz et al., 2011). Excessive hunting led to a bottleneck in the Hawaiian monk seal population and by 1958, growing concerns mounted regarding group numbers. As a result, the first monitoring and systematic beach survey programs began at this time (Schultz et al., 2011). Since then, field camps led by NOAA have been monitoring the critically threatened population of Hawaiian monk seals (Baker et al., 2012).

A similar story of excessive extraction followed by long-term scientific monitoring has been attributed to many of the once profitable fish species of the NWHI. Since the 1930s, bottomfish and other fish stocks have been commercially harvested in the NWHI including nearshore fish species such as trevally, also known as ulua (Moffitt 1980; Kittinger et al., 2010). These fishing efforts became more notable following World War II and continued until the early 1990s (Moffitt 1980; Friedlander et al., 2005; Schultz et al., 2011). The black-lipped pearl oyster was no exception, with approximately 150,000 individuals harvested between 1928 and 1930 (Keenan et al., 2006; Shallenberger 2006). In 1930, a survey for pearl oysters was conducted at Pearl and Hermes Atoll and only 480 individuals were found (Galtsoff 1933). The population was so badly depleted that a complete ban on the removal of the species was put in place in 1930 (Galtsoff 1933). To this day pearl oyster populations on Pearl and Hermes Atoll have not fully recovered (Keenan et al., 2006; Shallenberger 2006). Commercial fisheries for the Hawaiian spiny lobster and scaly slipper lobster became important in the 1970s, grossing \$6 million per year (Polovina 1993). The lobster fishery was eventually closed in 2000, and with the declaration of the Monument in 2006, fishing was gradually faded out of the region, culminating with the effective closing of all NWHI fisheries in July 2011. Stock assessments and scientific monitoring of fishing initiatives began with the Quadripartite Studies in the late 1970s, and are detailed below.

\section{HISTORICAL DEVELOPMENTS (1940s-1980s)}

Efforts to recover some of the species from extreme resource extraction began around the turn of the $20^{\text {th }}$ century. Other impacts influencing many of the unique species in the NWHI occurred as a result of habitat destruction mainly from military development at Midway Island, French Frigate Shoals and Kure Atoll (Ely and Clapp 1973; Friedlander et al., 2005; Keller et al., 2009). In 1909, President Theodore Roosevelt established a National Wildlife Bird Reservation including all of the NWHI, with the exception 


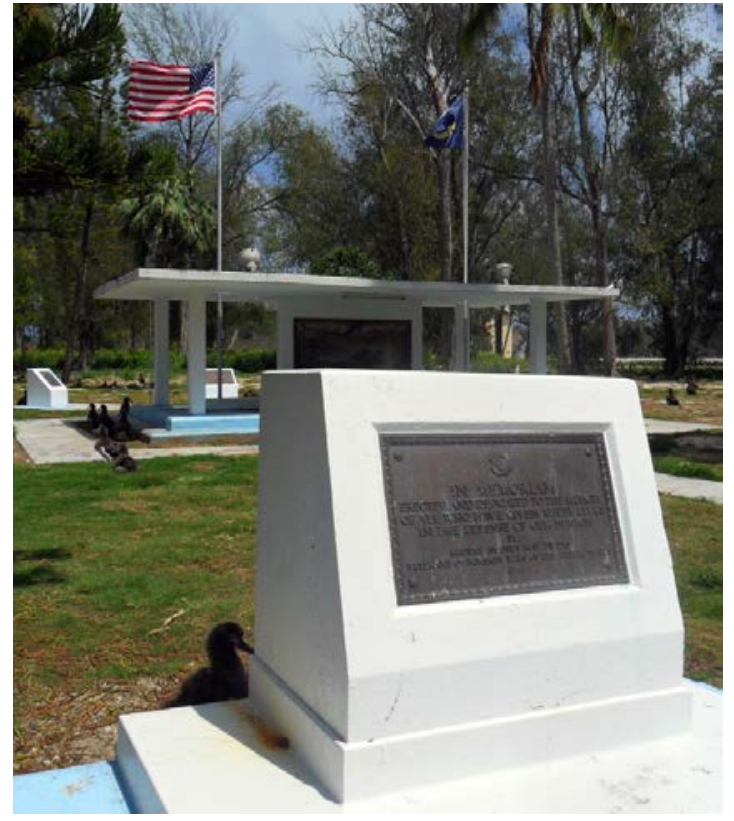

Figure 2. Battle of Midway National Memorial at Midway Atoll (Photo: Anne Rosinski/HIMB). of Midway Atoll (Bryan 1978; Yamase 1982; PMNM 2008). Midway Atoll was removed from the reserve because of its strong military presence and extensive development. In World War II, Midway became the center stage for one of key battles in the Pacific. On December 7, 1941 the Japanese bombed Midway, followed by the battle of Midway in June of 1942. This battle is still considered to be one of the major turning points of the war in the Pacific (Prange et al., 1982). On September $20^{\text {th }}, 2000$ this battle was commemorated with the Battle of Midway National Memorial at Midway Atoll (Figure 2). The memorial not only recognizes those who fought during World War II, but also honors the historical value of the PMNM.

Compared to the first phase of research dominated by the explorations of early naturalists, the second chapter of travel to the NWHI was characterized by mass removal and utilization of its natural resources, causing depletion of many valuable species. It was not until the 1960s and 1970s that travel for scientific endeavors was reignited in the NWHI. Two large

research programs operated in the NWHI at this time, including the Pacific Ocean Biological Ocean Program led by the Smithsonian Institution, and a multi-agency collaborative research agreement known as the Tripartite or Quadripartite Studies.

\section{Pacific Ocean Biological Survey Program}

Between 1962 and 1970, the Smithsonian Institution led a research program that aimed to increase the knowledge of the NWHI, as well as of various other islands in the Central Pacific. The program, known as the Pacific Ocean Biological Survey Program, included an extensive review of the literature, as well as several scientific expeditions to the NWHI. A series of comprehensive reports were published as a result of these explorations, including thorough monographs on the natural history of French Frigate Shoals (Amerson 1971), Gardner Pinnacles (Clapp 1972), Kure Atoll (Woodward 1972), Laysan Island (Ely and Clapp 1973), Pearl and Hermes Atoll (Amerson et al., 1974), Lisianski Island (Clapp and Wirtz 1975), Mokumanamana Island (Clapp and Kridler 1977) and Nīhoa Island (Clapp et al., 1977). These monographs contain detailed information on the biology, geology, geography, climate and human history of each of these islands visited as part of the Pacific Ocean Biological Survey Program.

\section{Tripartite/Quadripartite Studies}

In 1976 Congress passed a bill that gave the United States jurisdiction over waters extending out to 200 nautical miles off all U.S. states, territories and commonwealths. This development, along with increasing fishing pressures in the Main Hawaiian Islands, provided a major incentive to explore the fishery resources of the NWHI (Moffitt 1980; Grigg 2006). As a result, the National Marine Fisheries Service (NMFS), the U.S. Fish and Wildlife Service (USFWS) and the Hawai'i Division of Fish and Game (now Division of Aquatic Resources) signed a formal agreement in 1975 that sought to assess and survey the marine resources of the NWHI over a five year period (Grigg and Pfund 1980; Grigg and Tanoue 1984; Grigg 2006). Formally known as the NWHI Fishery Investigations, this collaborative agreement divided research foci between these three agencies, with NMFS being responsible for studies on offshore, bank and seamount resources, USFWS focusing on onshore and seabird research, and the Hawai'i Division of Fish and Game centering on nearshore investigations (Grigg 2006). Informally, the 
research agreement became known as the Tripartite Studies, because of the three agencies that were initially involved; however, the University of Hawai'i Sea Grant Program joined the agreement in 1977, thus giving rise to a Quadripartite Research Program (Grigg and Pfund 1980; Grigg and Tanoue 1984; Grigg 2006). Specifically, the Sea Grant Program joined forces with the Hawai'i Division of Fish and Game to conduct studies on the nearshore resources of the NWHI (Grigg 2006). In 1980, five years after the initial research period ended, the council for coordinating research for these investigations decided to extend research activities for an additional three years (Grigg and Tanoue 1984). Collectively, research funds totaling roughly \$10 million were invested in the Quadripartite Studies over eight years, and close to 200 scientists participated in this multidisciplinary research program (Grigg 2006). Stock assessments needed for managing fishery resources in the NWHI drove most of the research of the Quadripartite Studies (Moffitt 1980; Grigg 2006). Consequently, initial baselines for separate fishery management plans for (1) bottomfish, (2) pelagic species, (3) crustaceans and (4) precious corals were developed as a direct result of these studies (Grigg 2006). With the exception of precious corals, fisheries targeting these other groups have operated in the NWHI for at least some time (Parrish and Baco 2007; Kittinger et al., 2010). Thus, baseline data from the Quadripartite Studies has been essential to managing these fisheries in the NWHI (Grigg 2006). Additionally, individual recovery plans for the endangered Hawaiian monk seal and the threatened Hawaiian green turtle were later created as a result of the work performed under the Quadripartite Agreement (Grigg 2006). Therefore, the Quadripartite Studies have provided a great wealth of scientific information that has been essential for the management of marine resources in the NWHI (Grigg and Pfund 1980; Grigg and Tanoue 1984; Grigg 2006). Furthermore, in comparison to earlier scientific explorations, the Quadripartite Studies were the first to employ question and hypothesis driven science in the NWHI, as opposed to purely descriptive science, which characterized earlier research in this region (Grigg 2006).

Out of the Quadripartite Studies came two important research symposia on the NWHI which would later shape future research partnerships and set a precedent for sharing data in large conference settings. The first NWHI symposium took place on April 24-25, 1980 with 27 papers presented and 151 people in attendance (Grigg and Pfund 1980). Three years later a second NWHI symposium took place on May 2527, 1983 with 211 attendees (Grigg and Tanoue 1984). Results of these two NWHI research symposia were published in two symposium proceedings, which collectively encompass over 700 pages and a total of 115 reports, published and unpublished abstracts (Grigg and Pfund 1980; Grigg and Tanoue 1984). This phase of synthesis allowed for future research to work off of and take similar methods but apply them to newer technologies. These early symposia also laid the foundation for annual NWHI research symposia that started in 2006, and are presented later.

\section{RECENT SCIENTIFIC MONITORING (1980s-PRESENT)}

Since the mid-1980s reengagement of scientific monitoring and discovery in the NWHI has become an annual priority amongst University of Hawai'i, federal agencies including NOAA, the U.S. Fish and Wildlife, and State partners including the Hawai'i Division of Aquatic Resources. Monitoring programs such as Coral Reef Assessment and Monitoring Program (CRAMP) in the Main Hawaiian Islands and the Northwestern Hawaiian Islands Reef Assessment and Monitoring Program (NOWRAMP) have led to long-term data sets that are being used for ecosystem-based management to continually assess the abundance and distribution of marine species in the Hawaiian Island chain (Hamnett et al., 2004; Friedlander et al., 2005). Not only is this information pertinent to Hawai'i, it is also being used on a larger scale to estimate marine species distributions at various Pacific locations, including the U.S. Territories of Samoa and Guam, the Commonwealth of the Northern Mariana, Johnson Atoll, and the Pacific Remote Island Areas (see Williams et al., 2011). These efforts have been expanded into various annual management and research initiatives in the NWHI, including marine debris removal efforts, reef assessment and monitoring expeditions, maritime archeology surveys, exploration of mesophotic and deeper reefs, and investigations of intertidal regions (see Table 1; Figure 3). 
Table 1. Timeline of research initiatives and explorations of the Northwestern Hawaiian Islands.

\begin{tabular}{|l|l|}
\hline \multicolumn{1}{|c|}{ Expedition/Research Initiative } & \multicolumn{1}{c|}{ Time } \\
\hline Early Voyages & $1000-1700$ \\
\hline Hawaiian Monarchy Expeditions & $1822-1885$ \\
\hline Albatross Expedition & 1902 \\
\hline Tanager Expeditions & $1923-1924$ \\
\hline Pacific Ocean Biological Surveys & $1962-1970$ \\
\hline Quadripartite Studies & $1975-1983$ \\
\hline Marine debris surveys and removal & $1996-$ \\
& present \\
\hline Deep-sea surveys by the Hawai'i Undersea Research Laboratory & $1998-2011$ \\
(HURL) & \\
\hline NOWRAMP & $2000-$ \\
& present \\
\hline Northwestern Hawaiian Islands Research Partnership (NWHI-RP) & $2005-$ \\
& present \\
\hline Maritime heritage surveys & $2002-$ \\
& present \\
\hline Mesophotic coral reef surveys & $2009-$ \\
& present \\
\hline Intertidal surveys & $2011-$ \\
& present \\
\hline
\end{tabular}

\section{Marine Debris Surveys and Removal (1996-Present)}

Despite the isolated geographic location of the NWHI (Figure 1), the region is still impacted by various anthropogenic threats (Friedlander et al., 2005; Selkoe et al., 2008; Selkoe et al., 2009). Foremost among these threats are the global challenges of climate change, as well as the accumulation of marine debris and derelict fishing gear (Friedlander et al., 2005; Selkoe et al., 2008; Selkoe et al., 2009; Keller et al., 2009). Even though marine debris and fishing gear are not locally generated in the NWHI, these items accumulate at high rates in the region due to oceanographic circulation patterns that bring these objects from elsewhere in the Pacific (Kubota 1994; Donohue et al., 2000; Ingraham and Ebbesneyer 2001; Donohue 2005; Timmers et al., 2005; Pichel et al., 2007; Dameron et al., 2007; Morishige and McElwee 2012). In particular, the North Pacific Subtropical Convergence Zone, an area characterized by the convergence of surface waters just north of the NWHI between the latitudes of $28-34^{\circ} \mathrm{N}$, aggregates marine debris in the region that is then transported to the NWHI via tradewinds (Kubota 1994; Ingraham and Ebbesneyer 2001; Dameron et al., 2007; Harse 2011). Marine debris and derelict fishing gear cause major damages to reef organisms in the NWHI, by abrading and scouring living tissues of corals and other habitat forming organisms, as well as by entangling mobile species (Henderson 2001; Donohue 2003; Harse 2011). Since 1982, the NMFS has been removing marine debris from the beaches in the NWHI (Donohue et al., 2000; Donohue 2003; Timmers et al., 2005). Additionally, since 1996 dedicated expeditions have been launched annually to remove marine debris and derelict fishing gear from the shallow-water reefs of the NWHI (Donohue 2003; Timmers 2005; Friedlander et al., 2005). This multiagency effort involves many partners including the NOAA Coral Reef Ecosystem Division (CRED), PMNM, USFWS, the State of Hawai'i, the City and County of Honolulu, the U.S. Coast Guard, the U.S. Navy, the University of Hawai'i Sea Grant Program, Hawai'i Metals and Recycling, the Honolulu Waste Disposal, as well as various other agencies, non-governmental organizations and businesses (Donohue 2003; Timmers et al., 2005; Friedlander et al., 2005; Keller et al., 2009). 


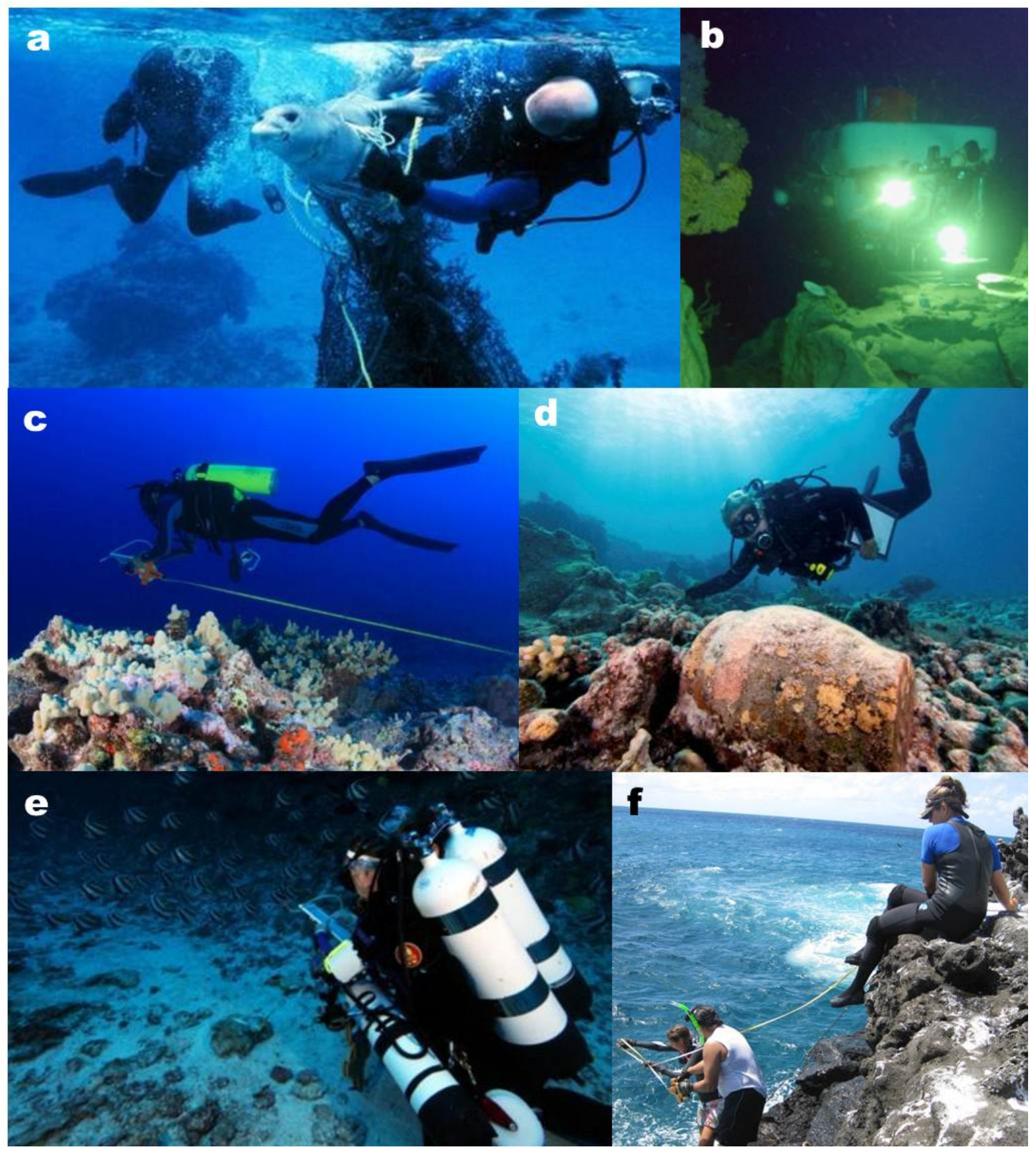

Figure 3. Recent research initiatives in the PMNM including (a) marine debris removal efforts, (b) deep-sea investigations by the Hawai' i Undersea Research Laboratory, (c) shallow -water reef assessments, (d) maritime archaeology surveys, (e) mesophotic coral reef surveys and (f) intertidal surveys. [Photos: (a) Ray Boland/NOAA; (b) Terry Kerby/HURL; (c-e) Greg McFall/NOAA; and (f) Hoku Johnson/NOAA]. 
Between 1996 and 2005, close to 500 metric tons of marine debris have been removed from the NWHI as part of these efforts, and brought back to Honolulu for their disposal, recycling or incineration to produce electricity (Friedlander et al., 2005; Timmers et al., 2005; Keller et al., 2009). Besides removing these major threats from the NWHI, this multi-agency effort has led to numerous scientific studies on (1) marine debris types (Henderson 2001; Donohue et al., 2001; Boland and Donohue 2003; Timmers et al., 2005; Morishige et al., 2007), (2) accumulation rates (Donohue et al., 2001; Boland and Donohue 2003; Boland et al., 2006; Dameron et al., 2007; Morishige et al., 2007), (3) at sea detection mechanisms (Pichel et al., 2007; Morishige and McElwee 2012) and (4) effects on monk seals and other organisms (Henderson 2001; Timmers et al., 2005).

\section{Recent Deep-Sea Investigations}

Spanning close to 2,000 km, the PMNM does not only stretch across an enormous horizontal area, but across a vast vertical range as well. With a spectrum of topography and bathymetry ranging from rugged island slopes at $275 \mathrm{~m}$ above sea level, to abyssal seafloor at over 4,500 m depths, the PMNM contains a great diversity of habitats. Investigations of the deeper areas of the NWHI started with the dredging efforts of the Albatross Expedition at the beginning of the $20^{\text {th }}$ century (see above). No other significant deep-sea collections were made until 1970, when the University of Hawai'i began a major research effort to investigate the distribution and abundance of precious corals across the Hawaiian Archipelago including the NWHI, a program commonly known as the Sango Expeditions (Grigg and Bayer 1976). The Sango Expeditions surveyed the deep-sea around the Hawaiian Islands primarily through dredges and tangle nets, and recorded many new organisms around Hawai'i (Grigg and Bayer 1976; Cairns 1984). In 1980, the Hawai'i Undersea Research Laboratory (HURL), a NOAA research center dedicated to deepsea explorations around Hawai'i and the Western Pacific, began its operations (Chave and Malahoff 1998). Since then, HURL has been surveying the deep-sea around Hawai'i through the use of remotely operated vehicles (ROVs) and submersibles (Chave and Malahoff 1998). The first HURL expedition to the NWHI was in 1984, when the HURL submersible Makali i performed a total of 14 dives to depths of 320-370 around French Frigate Shoals, Brooks Banks and Mokumanamana. No other HURL expeditions visited the NWHI until 1998, when 15 ROV and manned submersible dives were performed around French Frigate Shoals and Brooks Banks to depths of $580 \mathrm{~m}$. Since then, HURL has been exploring the deep waters of the NWHI regularly, with deep-sea missions surveying this region in 2000, 2001, 2002, 2003, 2007, 2009 and 2011. To date, HURL has performed a total of 256 dives across the NWHI to depths exceeding $2000 \mathrm{~m}$ (Figure 4), and supported a myriad of research efforts. These recent HURL explorations have greatly enhanced our understanding on the deep-sea in the NWHI, by providing new information on the (1) physical habitat features and maps of the region (Evans et al., 2004; Miller et al., 2004; Miller et al., 2006; Smith and Kelley 2010), (2) foraging behavior and habitat use of Hawaiian monk seals (Parrish et al., 2002; Parrish 2009; Parrish et al., 2011), (3) bottomfish and other deep-sea fish assemblages (Kelley et al., 2004; Mundy and Parrish 2004; Kelley and Ikehara 2006; Kelley et al., 2006; Parrish 2006), (4) scavenger communities on submarine canyons (Vetter et al., 2010); (5) taxonomy, systematics and biology of deep-sea corals (Cairns, 2005, 2009, 2010; Parrish 2006; Roark et al., 2006; Baco 2007; Parrish and Baco 2007; Waller and Baco 2007; Cairns and Bayer 2008; Parrish and Roark 2009; Baco and Cairns 2012), and (6) geology and geomorphology of the region (Rooney et al., 2008, and references therein). Despite these important discoveries, the Monument's waters below standard SCUBA diving depths (>30 m) still remain poorly surveyed and documented, representing an enormous opportunity for future scientific research in a system that is largely undisturbed from human perturbations. 


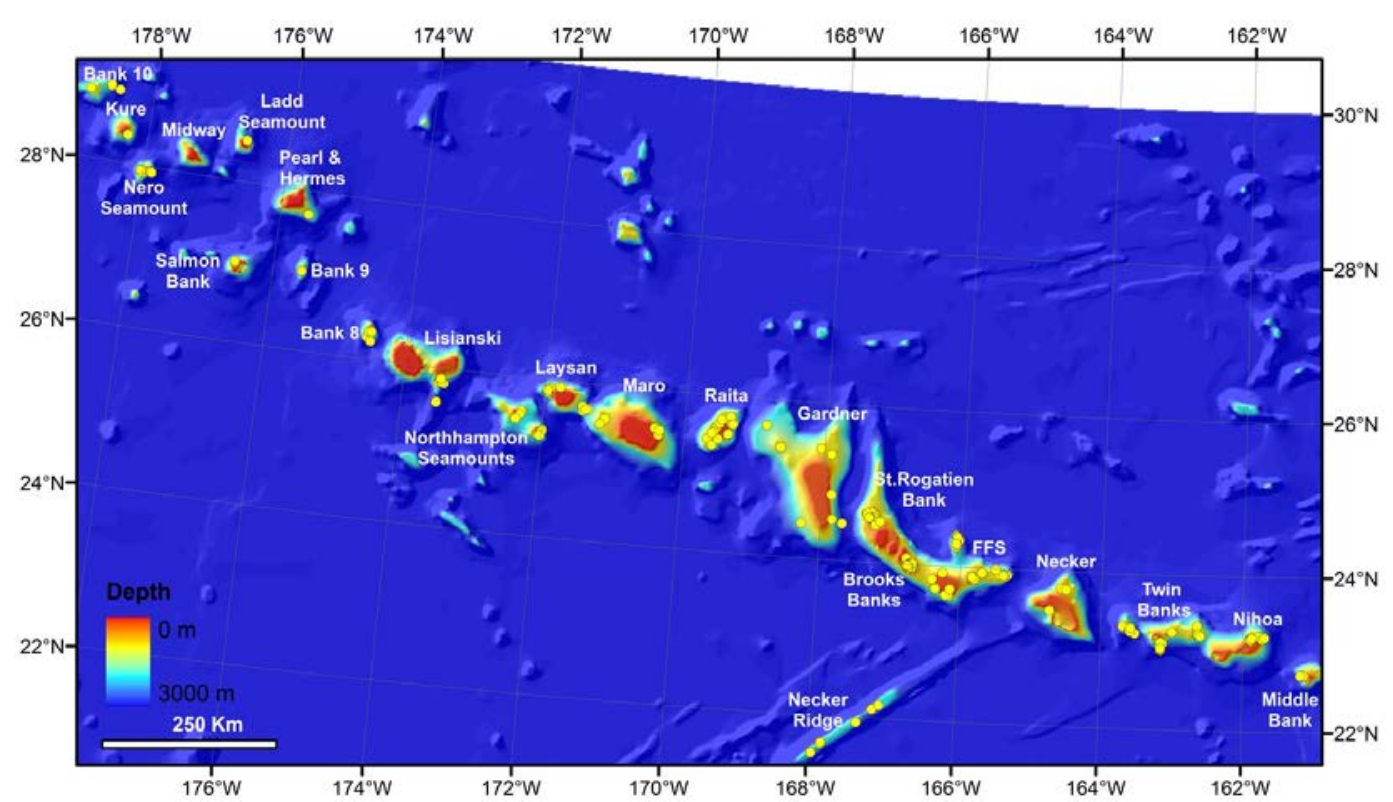

Figure 4. Map of manned submersible and ROV dives performed by HURL in the NWHI. These include a total of 256 dives to depths exceeding $2,000 \mathrm{~m}$.

\section{Shallow-Water Reef Assessments (2000-Present)}

The Reef Assessment and Monitoring Program (RAMP) is a Pacific wide program that monitors shallow-water coral reefs ( $<30 \mathrm{~m})$ across the majority of U.S. Pacific Islands and Territories including the Hawaiian Archipelago, the Mariana Archipelago, Wake Atoll, Johnston Atoll, Kingman Reef, Palmyra Atoll, Howland Island, Baker Island, Jarvis Island and American Samoa (Grigg 2006; Williams et al., 2011). Since 2000, RAMP has also been conducting annual monitoring surveys in the NWHI in collaboration with NOAA's Coral Reef Ecosystem Division, the PMNM and various other federal and state agencies and research institutions (Maragos et al., 2004; Hamnett et al., 2004; Friedlander et al., 2005; Grigg 2006). This monitoring effort, known as the Northwestern Hawaiian Islands Reef Assessment and Monitoring Program (NOWRAMP), collects information on the abundance and distribution of all major shallow-water $(<30 \mathrm{~m}$ ) reef organisms in the NWHI, including reef fish, algae, corals and other invertebrates (Friedlander and DeMartini 2002; Maragos et al., 2004; Preskitt et al., 2004; Friedlander et al., 2005; Vroom and Page 2006; Vroom et al., 2006). Additionally, NOWRAMP has taken advantage of recent technological advances in satellite technology and oceanographic instrumentation to study various oceanographic parameters in the NWHI (Friedlander et al., 2005). Since the inception of NOWRAMP in 2000, annual research expeditions have been launched to monitor coral reefs around all ten emergent islands, atolls and shallow-water $(<30 \mathrm{~m})$ shoals in the NWHI (Figure 1), thereby making it one of the most comprehensive monitoring programs of shallow-water coral reefs on the planet.

\section{Maritime Archaeology Surveys (2002-Present)}

Maritime heritage resources include the cultural, archaeological and historical traces of past seafaring and naval activities (PMNM 2008). The Hawaiian Islands have a rich maritime history, and the remnants of this are well preserved throughout the archipelago including the NWHI. During the late $18^{\text {th }}$ and early $19^{\text {th }}$ centuries, European and American traders began to call at the Main Hawaiian Islands, and by 1825 Honolulu became the most important port in the Pacific. During the late $19^{\text {th }}$ and early $20^{\text {th }}$ centuries, the NWHI were subjected to a series of extractive enterprises, including fishing, guano mining, shipwreck salvaging, turtle harvests, whaling, bird poaching and pearl oyster cultivation (see above). As a result, 
seafaring to the NWHI became increasingly common throughout the late $19^{\text {th }}$ and early $20^{\text {th }}$ century and many vessels ran aground, thus making Papahānaumokuākea a veritable graveyard of marine disaster (Gleason and Raupp 2010; Raupp and Gleason 2010). Two reasons for the frequent shipwrecks in the NWHI include the low, inconspicuous nature of the islands and atolls, which makes their shoals and reefs difficult to detect from above the water surface, and their often incorrect location on maritime charts. This, combined with the numerous extractive activities that have occurred over the past two centuries, has left a scattered material legacy on and around the NWHI, including shipwrecks and sunken naval aircraft. In fact, over 160 vessels and aircraft are thought to have been lost in the NWHI, including marine legendary whaling ships as well as aircrafts and vessels from World War II. The remote location of the NWHI has kept these maritime heritage resources safe from hundreds of years of salvage and looting. These submerged historical sites are international in scope and represent a cross section of the many cultures that engaged in Pacific seafaring history (PMNM 2008). Since 2002, roughly annual expeditions have been launched to document and inventory the rich maritime archaeological resources of PMNM (Friedlander et al., 2005; Gleason and Raupp 2010; Raupp and Gleason 2010). New sites are uncovered with each visit to this remote region, where maritime archaeologists have just begun to document the full extent of its material record. Some of the ship and aircraft wreck sites fall into the category of war graves associated with major historic events, such as the Battle of Midway. They are a physical record of past activities in the NWHI, embodying unique aspects of Pacific history and reflecting the region's past relevance in a global context.

\section{Mesophotic Coral Reef Surveys (2009-Present)}

Due to logistical constraints, the vast majority of surveys in the NWHI have been conducted in shallow waters ( $<30 \mathrm{~m}$ ) (Friedlander et al., 2005; Grigg et al., 2008). Additionally, some surveys have been performed in the deeper waters $(>100 \mathrm{~m})$ of the NWHI through the use of trawling and dredging performed as part of the Albatross and Sango Expeditions, as well as more recent explorations using HURL ROVs and manned submersibles (see above). However, as in many other regions around the world, little is known about the marine biodiversity between these two depth ranges (Rooney et al., 2010; Wagner et al., 2011). This intermediate depth range hosts mesophotic coral reef ecosystems (MCEs), which are light-dependent coral reef ecosystems found below the depth limit of conventional SCUBA diving (30 m), and extend to the deepest portion of the photic zone, which may be up to $150 \mathrm{~m}$ in some locations with high water clarity (Kahng et al., 2010; Rooney et al., 2010). MCEs have recently been prioritized for scientific study around the globe, due to a growing realization that their flora and fauna are diverse and unique, as well as vastly undersurveyed. For instance, the International Union for Conservation of Nature (IUCN) has identified MCEs as a top conservation priority due to their high levels of reef fish biodiversity (Sadovy 2007), and their importance as refugia for the globally degraded shallow-water reefs (Bongaerts et al., 2010; Kahng et al., 2010). Since 2009, annual research expeditions have been launched to survey MCEs within the PMNM using mixed-gas technical diving. Multiple significant discoveries have resulted from these expeditions including the collection of several previously undescribed species and the geographic range expansions of many known species (Wagner et al., 2011; Kane et al., in review). Perhaps the most significant finding is that the reef fish assemblages of NWHI MCEs are dominated by Hawaiian endemic species, which comprise $>90 \%$ of the numerical abundance and $>70 \%$ of the total number of fish species on some mesophotic reefs (Kane et al., in review). These findings indicate that MCEs in the NWHI represent important reservoirs of biodiversity, and further support the protection of the PMNM through the highest conservation standards available (Wagner et al., 2011; Kane et al., in review). Furthermore, these discoveries highlight the value of using cutting edge technologies such as mixed-gas technical diving to survey the largest portion of coral reef ecosystems (30-150 m) which remains largely unexplored. 


\section{Intertidal Surveys (2011-Present)}

Another habitat that has been largely under sampled in the NWHI is the intertidal, especially on the islands of Nīhoa and Mokumanamana, where large swells and rocky terrain combine to make the intertidal a particularly dangerous work environment (Clapp et al., 1977). Recognizing the lack of historical surveys targeting these habitats, the PMNM has launched expeditions to systematically study the intertidal in the NWHI in 2010, 2011 and 2012. While this research program is still in its infancy, it has already led to important discoveries on the biology and evolution of important intertidal species such as the endemic Hawaiian limpets or 'opihi (Bird et al., 2011; Toonen et al., 2011a).

\section{SCIENCE-MANAGEMENT INTEGRATION}

As exemplified above, scientific research has been carried out in the NWHI for many years, but regular monitoring efforts have only recently been formalized. One way that the ecosystem-based management of the NWHI has been apprised by science is through a partnership between the Hawai' $i$ Institute of Marine Biology (HIMB) and the NOAA Office of National Marine Sanctuaries (ONMS). This partnership began in 2005, one year prior to the Monument designation, and continues in the present day. The collaboration focuses on coral reef ecosystem research within the Hawaiian Archipelago, and more specifically within the PMNM. HIMB is a research facility that focuses on marine ecosystem science and resides in the School of Ocean and Earth Science and Technology (SOEST) at the University of Hawai'i at Mānoa. The research partnership is designed to generate data to assist decision makers using ecosystem-based management. Research emphasis has included understanding (1) connectivity through movement patterns and genetic population structures, (2) characterizing levels of coral reef health and biodiversity, (3) mapping and monitoring ecosystem threats such as climate change, and (4) providing education and outreach components on related science activities (Toonen et al., 2010; Toonen et al., 2011b). Annually, HIMB scientists travel to the NWHI aboard NOAA research cruises to conduct their work. To date, over 14 cruises covering the listed research topics above have gone out to the PMNM during the summer months.

Prior to the partnership, existing management and science agencies did not frequently share their work in a formalized setting. The HIMB NWHI-Research Partnership (NWHI-RP) has worked hard to overcome communication challenges and is a successful example of science management integration and collaborative communications (Wiener et al., 2011). Since 2007, over 200 publications in 35 journals have resulted from the research related to this partnership, including a special edition journal focusing on the science related to ecosystem-based management (Toonen et al., 2011b). Through the implementation of this science management collaboration, the NWHI has been the only place to complete a comprehensive community connectivity study. This research has also allowed for science to support social and ecological models for future resilience planning against the major effects of climate change like ocean acidification and sea-level rise (Selkoe et al., 2008; Selkoe et al., 2009).

\section{Growth of the Scientific Community and Symposia}

The need for communication of research results from scientists to managers is a critical element of ecosystem-based partnerships. This is a sentiment that has been echoed by many agencies that have requested improved communication between scientists and mangers (Morgan et al., 2010). Recently, there have been many calls to action, and the NWHI-RP has been answering these calls through implementation of collaborative communication mechanisms like research symposia and reports that integrate science and management. These initiatives have been ongoing since the partnership was initiated in 2005. How scientists convey their research to managers, policy makers, and the public plays an important role in decision making within ecosystem-based management (Wiener et al., 2011).

The first two NWHI research symposia took place during the Quadripartite Research Program in the early 1980s (see above; Grigg and Pfund 1980; Grigg and Tanoue 1984). These two symposiums 
established a format that would later be remodeled and used as a basis for future meetings. In 2004, a third research symposium showcased research and management achievements in the NWHI (Macintyre 2006). Since the NWHI-RP was established, annual symposia have been held (see Table 2). The main partners included in these annual meetings include scientists and managers from the University of Hawai'i, PMNM and NOAA's Pacific Islands Fisheries Science Center (PIFSC). These symposia emphasize good leadership, sharing a similar language from frequent communications (i.e., scientists and managers learning to communicate with each other), and intentionally bringing university and government scientists together to form new collaborations. Each year these symposia have continued to grow, from 57 participants in 2007 to over 220 participants in 2012 (see Table 2).

Table 2. NWHI symposium attendance from 1980-present.

\begin{tabular}{|c|l|c|}
\hline Year & \multicolumn{1}{|c|}{ Venue } & Attendance \\
\hline 1980 & Campus Center Ballroom, University of Hawai'i at Mānoa & 151 \\
\hline 1983 & Campus Center Ballroom, University of Hawai'i $i$ at Mānoa & 211 \\
\hline 2004 & Hawai'i Convention Center & 155 \\
\hline 2007 & Windward Community College & 57 \\
\hline 2008 & Windward Community College & 136 \\
\hline 2009 & East-West Center, University of Hawai'i at Mānoa & 169 \\
\hline 2011 & East-West Center, University of Hawai'i at Mānoa & 205 \\
\hline 2012 & East-West Center, University of Hawai'i $i$ at Mānoa & 220 \\
\hline
\end{tabular}

\section{Success of the Science-Management Integration}

Through the NWHI-RP, over 74 people have worked together to provide scientific data for ecosystem-based management. Following the completion of the first five years of the partnership, a science management integration project was initiated to examine partnership success and to explore areas in need of revision. A group from the partnership was selected to evaluate and make recommendations based on round-table discussions, focus groups and survey results.

A survey was conducted using participants of the NWHI-RP and those who have been involved in previous research symposia. Findings from survey and round table discussions showed that the partnership has been successful in introducing a distinctive approach that allows for science-based management using current research. Within the survey, $67 \%$ of respondents were satisfied with the achievements of the NWHI-RP. General scientific research support for ecosystem-based management was highlighted as being successfully accomplished. Survey respondents agreed that management decisions based on science are important in effectively managing marine resources, with $100 \%$ of managers and $91 \%$ of scientists strongly agreeing with this statement. This was the highest ranked statement throughout the entire survey, showing consensus and support for science-based decision making. Respondents also agreed (77\%) with the statements that current management and scientific research have led to a better conservation of NWHI ocean resources.

\section{CONCLUSION}

A vast inventory of integrated knowledge has been accumulated by many generations of explorers ranging from early Hawaiian voyagers, to fishermen and guano minors, to present-day scientists. Looking back, there are distinct historical phases of research in the NWHI, starting with early collections and resource extractions, and then culminating with present day scientific monitoring. All phases of navigation steamed from an interest in discovery and an affinity for the ocean. These events and phases have naturally evolved as political and management structures surrounding the oceans and navigation have changed, and equally been influenced by the changing technology brought on by new 
instrumentation. Taken together, syntheses from these explorations have produced a wealth of knowledge, thereby giving us the abilities to monitor and understand the remote NWHI ecosystems that we know today. As demonstrated in this article, isolated expeditions have shifted from small-scale extraction voyages, to larger-scale and continuous research missions. We no longer have a focus just in the Hawaiian Islands, but are branching out to archipelagic-wide science and management across the broader Pacific. This expansion is not only horizontal, but also vertical, exploring new frontiers in deep-sea and mesophotic research.

The last question that remains is what will drive future research initiatives? With a rapidly changing climate, and the ocean reflecting these shifts, what science can we use to help predict and adapt to these new conditions? Additionally, with the integration of science and management, more forward thinking surrounding Western science and local knowledge will allow for the blending of different ways of knowing. Moving forward, scientists working in the PMNM will need to continue to define questions that drive research, and explore how we can better manage for environmental shifts in climate. Reflecting back on how these past histories have influenced our present day directions is important, as they play a role in how they shape our future.

\section{ACKNOWLEDGEMENTS}

This work was supported by NOAA's Office of National Marine Sanctuaries, the Papahānaumokuākea Marine National Monument, the State of Hawai'i Department of Land and Natural Resources, the Hawai'i Division of Aquatic Resources, the U.S. Fish and Wildlife Service, and COSEE Island Earth. Additional funding was provided by NMSP MOA 2005-008/6882. Special thanks to 'Aulani Wilhelm, Randall Kosaki, Jo-Ann Leong, and Robert Toonen for their valuable contributions. This is HIMB contribution number 1542 and SOEST contribution number 8859.

\section{REFERENCES}

Amerson, B. 1971. The natural history of French Frigate Shoals, Northwestern Hawaiian Islands. Atoll Research Bulletin 150: 383pp.

Amerson, B., R.C. Clapp, and W.O. Wirtz. 1974. The natural history of Pearl and Hermes Reef, Northwestern Hawaiian Islands. Atoll Research Bulletin 174: 306pp.

Allard, D.C. 1999. The origins and early history of the steamer Albatross, 1880-1887. Marine Fisheries Review 61(4): 1-21.

Allard, D.C., J.R. Moring, D.G. Smith, J.T. Williams, V.G. Springer, A.P. Summers, K.E. Hartel, T.J. Koob, and D.M. Damkaer. 1999. The U.S. Fish Commission steamer Albatross: a history. Marine Fisheries Review 61: i-vii.

Athens, J.S., J.V. Ward, and D.W. Blinn. 2007. Vegetation history of Laysan Island, Northwestern Hawaiian Islands. Pacific Science 61: 17-37.

Baco, A.R. 2007. Exploration for deep-sea corals on North Pacific Seamounts and Islands. Oceanography 20: $108-117$.

Baco, A.R., and S.D. Cairns. 2012. Comparing molecular variation to morphological species designations in the deep-sea coral Narella reveals new insights into seamount coral ranges. PLOS One: e45555.

Baker, J.D., E.A. Howell, and J.J. Polovina. 2012. Relative influence of climate variability and direct anthropogenic impact on a sub-tropical Pacific top predator, the Hawaiian monk seal. Marine Ecology Progress Series 469: 175-189.

Bayer, F.M. 1952. Descriptions and redescriptions of the Hawaiian octocorals collected by the U.S. Fish Commission steamer "Albatross." (1. Alcyonacea, Stolonifera, and Telestacea.). Pacific Science 6(2): 126-136.

- 1956. Descriptions and redescriptions of the Hawaiian octocorals collected by the U.S. Fish Commission steamer "Albatross." (2. Gorgonacea: Scleraxonia). Pacific Science 10: 67-95. 
Beckwith, M.W. 1949. Function and meaning of the Kumulipo birth chant in ancient Hawai'i. The Journal of American Folklore 62(245): 290-293.

Bell, A.M. 2007. Historic voyage as a catalyst for inspiring change. Proceedings of the $8^{\text {th }}$ World Wilderness Congress Symposium: 422-427.

Berry, S.S. 1912. The Cephalopoda of the Hawaiian Islands. Bulletin of the Bureau of Fisheries 32: 257362.

Bird, C.E., B.S. Holland, B.B. Bowen, and R.J. Toonen. 2011. Diversification of sympatric broadcastspawning limpets (Cellana spp.) within the Hawaiian archipelago. Molecular Ecology 20: 2128-2141.

Boland, R.C., and M. Donohue. 2003. Marine debris accumulation in the nearshore marine habitat of the endangered Hawaiian monk seal, Monachus schauinlandi 1999-2001. Marine Pollution Bulletin 46: 1385-1394.

Boland, R.C., B. Zgliczynski, J. Asher, A. Hall, K. Hogreffe, and M. Timmers. 2006. Dynamics of debris densties and removal at the Northwestern Hawaiian Islands coral reefs. Atoll Research Bulletin 543: 461-710.

Bongaerts, O., T. Ridgway, E.M. Sampayo, and O. Hoegh-Guldberg. 2010. Assessing the 'deep reef refugia' hypothesis: focus on Caribbean reefs. Coral Reefs 29: 309-327.

Bowers, G.M. 1903. Records of the dredging and other collecting stations of the U.S. Fish Commission steamer Albatross in 1901 and 1902. U.S. Fish Commission Report for 1902: 397-492.

Bryan, E.H., P.H. Timberlake, W.M. Wheeler, R.H. Van Zwaluwenberg, R.C.L. Perkins, R.C. Shannon, O.H. Swezey, M. Hebard, and R.V. Chamberlian. 1926. Insects of Hawai'i, Johnston Islands and Wake Islands. Bernice P. Bishop Museum Bulletin 31: 94pp.

Bryan, E.H. 1978. The Northwestern Hawaiian Islands: an annotated bibliography. U.S. Fish and Wildlife Service. Honolulu, Hawai'i: 136pp.

Butler, G.D., and R.L. Usinger. 1963. Insects and other invertebrates from Laysan Island. Atoll Research Bulletin 98: 30pp.

Cairns, S.D. 1984. New records of ahermatypic corals (Scleractinia) from the Hawaiian and Line Islands. Bishop Museum Occasional Papers 25(10): 1-30.

- 2005. Revision of the Hawaiian Stylasteridae (Cnidaria: Hydrozoa: Athecata). Pacific Science 59(3): 439-451.

- 2009. Review of Octocorallia (Cnidaria: Anthozoa) from Hawai'i and adjacent seamounts. Part 2: genera Paracalyptrophora Kinoshita, 1908; Candidella Bayer, 1954; and Calyptrophora Gray, 1866. Pacific Science 63(3): 413-448.

- 2010. Review of Octocorallia (Cnidaria: Anthozoa) from Hawai'i and adjacent seamounts. Part 3: Genera Thouarella, Plumarella, Callogorgia, Fanellia, and Parastenella. Pacific Science 64(3): 413-440.

Cairns, S.D., and F.M. Bayer. 2008. A review of the Octocorallia (Cnidaria:Anthozoa) from Hawai'i and adjacent seamounts: the genus Narella Gray, 1870. Pacific Science 62(1): 83-118.

Chave, E.H., and A. Malahoff. 1998. In deeper waters: photographic studies of Hawaiian deep-sea habitats and life-forms. Honolulu, HI. University of Hawai'i Press: 136pp.

Christophersen, E., and E.L. Caum. 1931. Vascular plants of the Leeward Islands, Hawai'i. Bernice P. Bishop Museum Bulletin 81: 41pp.

Clapp, R.B. 1972. The natural history of Gardner Pinnacles, Northwestern Hawaiian Islands. Atoll Research Bulletin 163: 25pp.

Clapp, R.B., and W.O. Wirtz. 1975. The natural history of Lisianski Island, Northwestern Hawaiian Islands. Atoll Research Bulletin 186: 196pp.

Clapp, R.B., E. Kridler, and R.R. Fleet. 1977. The natural history of Nīhoa Island, Northwestern Hawaiian Islands. Atoll Research Bulletin 207: 147pp.

Clapp, R.B., D.F. Udvardy, and A.K. Kepler. 1996. An annotated bibliography of Laysan Islands, Northwestern Hawaiian Islands. Atoll Research Bulletin 434: 92pp.

Cleghorn, P.L. 1988. The settlement and abandonment of two Hawaiian outposts: Nīhoa and Necker Islands. Bishop Museum Occasional Papers 28: 35-49. 
Coe, W.R. 1903. Nermeteans of the Hawaiian Islands collected by the steamer Albatross in 1902. U.S. Fish Commission Bulletin (1903, Part III): 975-986.

Dameron, O., M. Parke, M. Albins, and R. Brainard. 2007. Marine debris accumulation in the Northwestern Hawaiian Islands: an examination of rates and processes. Marine Pollution Bulletin 54: 423-433.

Dana, J.D. 1846. Zoophytes. U.S. Exploring Expedition during the years 1838-42. Vol. 7: 740pp.

Donohue, M. 2003. How multiagency partnerships can successfully address large-scale pollution problems: a Hawai'i case study. Marine Pollution Bulletin 46: 700-702.

- 2005. Eastern Pacific Ocean source of Northwestern Hawaiian Islands marine debris supported by errant fish aggregating device. Marine Pollution Bulletin 50: 886-888.

Donohue, M., R. Brainard, M. Parke, and D. Foley. 2000. Mitigation of environmental impacts of derelict fishing gear through debris removal and environmental monitoring. Proceedings from the 4th International Marine Debris Conference on Derelict Fishing Gear and the Marine Environment: 5878.

Donohue, M., R. Boland, C. Sramek, and G. Antonelis. 2001. Derelict fishing gear in the Northwestern Hawaiian Islands: diving surveys and debris removal confirm threat to coral reef ecosystems. Marine Pollution Bulletin 42(12): 1301-1312.

Duffy, D.C. 2010. Changing seabird Management in Hawai'i: from exploitation through management to restoration. Waterbirds 33(2): 193-207.

Edmonson, C.H., W.K. Fisher, H.L. Clark, A.L. Treadwell, and J.A. Cushman. 1925. Marine zoology of the tropical central Pacific. Bishop Museum Bulletin: 148pp.

Ely, C.A., and R.B. Clapp. 1973. The natural history of Laysan Island, Northwestern Hawaiian Islands. Atoll Research Bulletin 171: 361pp.

Emory, K.P. 1928. Archaeology of Nīhoa and Necker Islands. Bishop Museum Bulletin 53: 124pp.

Evans, B.K., J.R. Smith, and J.E. Miller. 2004. Collaborative nautical charting and scientific seabed mapping missions: NOAA and the University of Hawai'i conduct a case study in the Northwestern Hawaiian Islands. Sea Technology 45(6): 14-22.

Finney, B. 2003. Sailing in the wake of the ancestors: reviving Polynesia Voyaging. Bishop Museum Press. Honolulu, Hawai'i: 168pp.

Fisher, W.K. 1907. The holothurians of the Hawaiian Islands. Proceedings of the U.S. National Museum 32(1555): 637-740.

Fowler, H.W., and S.C. Ball. 1925. Descriptions of new fishes obtained by the Tanager Expedition of 1923 in the Pacific Islands west of Hawai'i. Proceedings of the Academy of Natural Sciences of Philadelphia 76: 269-274.

Friedlander, A.M., and E.E. DeMartini. 2002. Contrasts in density, size, and biomass of reef fishes between the northwestern and the main Hawaiian islands: the effects of fishing down apex predators. Marine Ecology Progress Series 230: 253-264.

Friedlander, A., G. Aeby, R. Brainard, A. Clark, E. DeMartini, S. Godwin, J. Kenyon, J. Maragos, and P. Vroom. 2005. The state of coral reef ecosystems of the northwestern Hawaiian Islands. Pages 270311. in J. Weddel, editor. The State of Coral Reef Ecosystems of the United States and Pacific Freely Associated States: 2005. NOAA Technical Memorandum NOS NCCOS 1. NOAA/NCCOS Center for Coastal Monitoring and Assessment's Biogeography Team. Silver Spring, MD. 522pp.

Galtsoff, P.S. 1933. Pearl and Hermes Reef, Hawaii hydrographical and biological observations. Bernice P. Bishop Museum Bulletin 107: 49.

Gilbert, C.H. 1903. The deep-sea fishes of the Hawaiian Islands. Bulletin of the United States Fish Commission 23 (1903, Part II): 577-713.

Gleason, K., and J.T. Raupp. 2010. Lost and found in Papahānaumokuākea Marine National Monument: the possible wreck site of the Nantucket Whaleship Two Brothers. Historic Nantucket 60(3): 13-17.

Grigg, R.W., and R.T. Pfund. 1980. Proceedings of the symposium of Status of Resource Investigations in the Northwestern Hawaiian Islands. UNIHI-SeaGrant-MR-80-04. 333pp.

Grigg, R.W., and R.T. Tanoue. 1984. Proceedings of the second symposium of Status of Resource Investigations in the Northwestern Hawaiian Islands. UNIHI-SeaGrant-MR-84-01. 491pp. 
Grigg, R.W. 1988. Paleoceanography of coral reefs in the Hawaiian-Emperor Chain. Science 240(4860): 1737-1743.

. 1997. Paleoceanography of coral reefs in the Hawaiian-Emperor Chain - revisited. Coral Reefs 16(Suppl.): S33-S38.

- 2006. The history of marine research in the Northwestern Hawaiian Islands: lessons from the past and hopes for the future. Atoll Research Bulletin 543: 13-22.

Grigg, R.W., J. Polovia, A.M. Friedlander, and S.O. Rohman. 2008. Biology of coral reefs in the Northwestern Hawaiian Islands. Pages 573-594. in B.M. Riegl, and R.E. Dodge, editors. Coral Reefs of the USA. Springer.

Hamnett, M.P., K. Davidson, W. Devick, L.G. Eldredge, K. Foster, J.A. Leong, R. Nishimoto, F. Oishi, and C. Smith. 2004. Introduction to special Hawai'i Coral Reef Initiative Research Program volume. Pacific Science 58(2): 143-144.

Harse, G.A. 2011. Plastic, the great pacific garbage patch, and international misfires at a cure. Journal of Environmental Law 29: 331-363.

Henderson, J. 2001. A pre- and post-MARPOL Annex V summary of Hawaiian monk seal entanglements in marine debris accumulation in the Northwestern Hawaiian Islands, 1982-1998. Marine Pollution Bulletin 42(7): 584-589.

Ingraham, W.J., and C.C. Ebbesneyer. 2001. Surface current concentration of floating marine debris in the North Pacific Ocean: 12-year OSCURS model experiments. Proceedings of the International Marine Debris Conference on Derelict Fishing Gear and the Ocean Environment. August 6-11, 2000. Honolulu, HI.

Jokiel, P.L., K.S. Rodgers, W.J. Walsh, D.A. Polhemus, and T.A. Wilhelm. 2011. Marine resource management in the Hawaiian Archipelago: the traditional Hawaiian system in relation to the Western approach. Journal of Marine Biology Special Issue: Ecosystem-Based Management of Pacific Islands: Article ID 151682, 16pp.

Jokilehto, J. 2010. World heritage: observations on decisions related to cultural heritage. Journal of Cultural Heritage Management and Sustainable Development 1: 61-74.

Kahng, S.E., J.R. Garcia-Sais, H.L. Spalding, E. Brokovich, D. Wagner, E. Weil, L. Hinderstein, R.J. Toonen. 2010. Community ecology of mesophotic coral reef ecosystems. Coral Reefs 29: 255-275.

Kane, C., R.K. Kosaki, and D. Wagner. In review. High levels of mesophotic ree fish endemism in the Northwestern Hawaiian Islands. Deep-Sea Research II.

Keenan, K.K., R.E. Brainard, and L.V. Basch. 2006. Historical and present status of the pearl oyster, Pinctada margaritifera, at Pearl and Hermes Atoll, Northwestern Hawaiian Islands. Atoll Research Bulletin 543: 333-344.

Keller, K.E., A.D. Anders, A. Mooney, R. Kosaki, M. Chow, and M. Monaco. 2009. Management Concerns and responsabilities. Pages 331-363. in A. Friedlander, K. Keller, L. Wedding, A. Clarke, and M. Monaco, editors. A Marine Biogeographic Assessment of the Northwestern Hawaiian Islands. NOAA Technical Memorandum NOS NCCOS 84, Silver Spring, MD. 363pp.

Kelley, C.D., and W. Ikehara. 2006. The impacts of bottomfishing on Raita and West St. Rogatien Banks in the Northwestern Hawaiian Islands. Atoll Research Bulletin 543: 305-318.

Kelley, C.D., R. Moffitt, and J.R. Smith. 2006. Mega to micro-scale classification and description of bottomfish essential fish habitat on four banks in the Northwestern Hawaiian Islands. Atoll Research Bulletin 543: 319-332.

Kittinger, J.N., K.N. Duin, and B.A. Wilcox. 2010. Commercial fishing, conservation and compatibility in the Northwestern Hawaiian Islands. Marine Policy 34: 208-217.

Kubota, M. 1994. A mechanism for the accumulation of floating marine debris north of Hawaii. Journal of Physical Oceanography 5: 1059-1064.

Lamoureux, C.H. 1963. The flora and vegetation of Laysan Island. Atoll Research Bulletin 97: 20pp.

Macintyre, I.G. 2006. Proceedings of the Northwestern Hawaiian Islands Third Scientific Symposium. Atoll Research Bulletin 543: 581pp. 
Maragos, J.E., D.C. Potts, G. Aeby, D. Gulko, J. Kenyon, D. Siciliano, and D. VanRavensway. 2004. 2000-2002 rapid ecological assessment of corals (Anthozoa) on shallow reefs of the Northwestern Hawaiian Islands. Part 1: species and distribution. Pacific Science 58(2): 211-230.

Miller, J.E., R.K. Hoeke, T.B. Appelgate, P.J. Johnson, J. Smith, and S. Bevacqua. 2004.Bathymetric Atlas of the Northwestern Hawaiian Islands. National Oceanic and Atmospheric Administration: 65 pp.

Miller, J.E., S. Vogt, R. Hoeke, S. Ferguson, T.B. Appelgate, J.R. Smith, and M. Parke. 2006. Bathymetric atlas and website for the Northwestern Hawaiian Islands. Atoll Research Bulletin 543: 409-422.

Moffitt, R.B. 1980. A preliminary report on bottomfishing in the Northwestern Hawaiian Islands. Pages 216-225. in R.W. Grigg, and R.T. Pfund, editors. Proceedings of the Symposium on Status of Resource Investigations in the Northwestern Hawaiian Islands. UNIHI-SEAGRANT-MR-80-04.

Morgan, L., W. Chandler, E. Douce, S. Brooke, J. Guinotte, and S. Myhre. 2010. Research priorities for the Pacific Remote Islands Marine National Monument. Research report by the Marine Conservation Biology Institute (MCBI), www.mcbi.org/publications/publications.htm.

Morishige, C., M.J. Donohue, E. Flint, C. Swenson, and C. Woolaway. 2007. Factors affecting marine debris deposition at French Grigate Shoals, Northwestern Hawaiian Islands Marine National Monument, 1990-2006. Marine Pollution Bulletin 54: 1162-1169.

Morishige, C., and K. McElwee, 2012. At-sea detection of derelict fishing gear in the North Pacific: an overview. Marine Pollution Bulletin 65: 1-6.

Mundy, B.C., and F.A. Parrish. 2004. New records of the fish genus Grammatonotus (Teleostei: Perciformes: Percoidei: Callanthiidae) from the Central Pacific, including a spectacular species in the Northwestern Hawaiian Islands. Pacific Science 58(3): 403-417.

Nares, G.S., and F.T. Thomson. 1895. Report of the scientific results of the voyage of H.M.S. Challenger during the years 1872-76. Vol.1-2: 1607 and 73 pp.

Nutting, C.C. 1903. Hydroids of the Hawaiian Islands collected by the steamer Albatross in 1902. U.S. Fish Commission Bulletin (1903, Part III): 931-959.

- 1908. Descriptions of the Alcyonaria collected by the U.S. Bureau of Fisheries Steamer Albatross in the vicinity of the Hawaiian Islands in 1902. Proceedings of the United States National Museum 34(1624): 543-601.

Olson, S. L. 1996. History and ornithological journals of the Tanager Expedition of 1923 to the Northwestern Hawaiian Islands, Johnston and Wake Islands. Atoll Research Bulletin 433: 216pp.

Olson, S. L., and H.F. James. 1994. A chronology of ornithological exploration in the Hawaiian Islands, from Cook to Perkins. Studies in Avian Biology 15: 91-102.

Our Sea of Islands. 2007. Our Sea of Islands communiqué - a regional forum for Oceania on marine managed areas and world heritage. January 29-February 2, 2007. Honolulu, HI: 4pp.

Palmer, H.S. 1927. Geology of Ka'ula, Nīhoa, Necker, and Gardner Islands, and French Frigate Shoal. Bernice P. Bishop Museum Bulletin 35: 35pp.

Papahānaumokuākea Marine National Monument. 2008. Papahanaumokuakea Marine National Monument Management Plan. Vol. 1. Honolulu, Hawai'i. 372 pp.

Parrish, F.A., K. Abernatry, G.A. Marshall, and B.M. Buhleier. 2002. Hawaiian Monk Seals (Monachus schauinslandi) foraging in deep-water coral beds. Marine Mammal Science 18(1): 244-258.

Parrish, F.A., E.A. Howell, G.A. Antonelis, S.J. Iverson, C.L. Littnan, J.D. Parrish, and J.J. Polovina. 2011. Estimating the carrying capacity of French Frigate Shoals for the endangered Hawaiian monk seal using Ecopath with Ecosim. Marine Mammal Science 28(3): 522-541.

Parrish, F.A. 2006. Precious corals and subphotic fish assemblages. Atoll Research Bulletin 543: 425-439.

- 2009. Do monk seals exert top-down pressure in subphotic ecosystems? Marine Mammal Science 25(1): 91-106.

Parrish, F.A., and A.R. Baco. 2007. State of deep coral ecosystems in the U.S. Pacific Islands region: Hawai' $i$ and the U.S. Pacific territories. Pages 159-194. in: S.E. Lumsden, T.F. Hourigan, A.W. Bruckner, and G. Dorr, editors. The state of deep coral ecosystems in the United States. NOAA Technical Memorandum CRCP - 3, Silver Spring, MD. 
Parrish, F.A., and E.B. Roark. 2009. Growth validation of gold coral Gerardia sp. in the Hawaiian Archipelago. Marine Ecology Progress Series 397: 163-172.

Pichel, W., J. Churnside, T. Veenstra, D. Foley, K.Friedman, R. Brainard, J. Nicoll, Q. Zheng, and P. Clemente-Colon. 2007. Marine debris collects within the North Pacific Subtropical Convergence Zone. Marine Pollution Bulletin 54: 1207-1211.

Polovina, J.J. 1993. The lobster and shrimp fisheries in Hawaii. Marine Fisheries Review 55 (2): 28-33.

Prange, G.W., D.M. Goldstein, K.V. Dillon. 1982. Miracle at Midway. McGraw-Hill. New York, New York: 512pp.

Preskitt, L.B., P.S. Vroom, and C.M. Smith. 2004. A rapid ecological assessment (REA) quantitative survey method for benthic algae using photoquadrats with scuba. Pacific Science 58: 201-209.

Raupp, J.T., and K.A. Gleason. 2010. Submerged whaling heritage in Papahānaumokuākea Marine National Monument. Bulletin of the Australasian Institute for Maritime Archaeology 34: 66-74.

Rauzon, M.J. 2001. Isles of refuge: wildlife and history of the Northwestern Hawaiian Islands. University of Hawai'i Press. Honolulu, HI: 207pp.

Rieser, A. 2012. The Papahānaumokuākea precedent: ecosystem-scale marine protected areas in the EEZ. Asia-Pacific Law \& Policy Journal 13(2): 210-251.

Roark, E.B., T.P. Guilderson, R.B. Dunbar, and B.L. Ingram. 2006. Radiocarbon-based ages and growth rates of Hawaiian deep-sea corals. Marine Ecology Progress Series 327: 1-14.

Rooney, J.J., P. Wessel, R. Hoeke, J. Weiss, J. Baker, F. Parrish, C.H. Fletcher, J. Chojnacki, M. Garcia, R. Brainard, and P. Vroom. 2008. Geology and geomorphology of coral reefs in the Northwestern Hawaiian Islands. Pages 519-571. in B.M. Riegl, and R.E. Dodge, editors. Coral Reefs of the USA. Springer.

Rooney, J., E. Donham, A. Montgomery, H. Spalding, F. Parrish, R. Boland, D. Fenner, J. Gove, and O. Vetter. 2010. Mesophotic coral ecosystems in the Hawaiian Archipelago. Coral Reefs 29(2): 361-367.

Sadovy, Y. 2007. Final report: workshop for global red list assessments of groupers family Serranidae; subfamily Epinephelinae. University of Hong Kong. Available online at: http://www.hku.hk/ecology/GroupersWrasses/iucnsg/.

Schultz, J.K., J.J. O'Malley, E.E.Kehn, J.J. Polovina, F.A. Parrish, and R.K. Kosaki. 2011. Tempering expectations of recovery for previously exploited populations in a fully protected marine reserve. Journal of Marine Biology Special Issue: Ecosystem-Based Management of Pacific Islands. Article ID 749131, 14pp.

Selkoe, K.A., B.S. Halpern, and R.J. Toonen. 2008. Evaluating anthropogenic threats to the Northwestern Hawaiian Islands. Aquatic Conservation: Marine and Freshwater Ecosystems 18: 1149-1165.

Selkoe, K.A., B.S. Halpern, C.M. Ebert, E.C. Franklin, E.R. Selig, K.S. Casey, J. Bruno, and Toonen, R.J. 2009. A map of human impacts to a "pristine" coral reef ecosystem, the Papahānaumokuākea Marine National Monument. Coral Reefs 28: 635-650.

Shallenberger, R.J. 2006. History of management in the Northwestern Hawaiian Islands. Atoll Research Bulletin 543: 23-31.

Smith, J.R., and C.D. Kelley. 2010. Multibeam synthesis of the Northwestern Hawaiian Islands supports diverse research in the Papahānaumokuākea Marine National Monument. AGU Meeting, Dec. 13-17, 2010. San Francisco, CA: Abstract OS13C-1240.

Snyder, J.O. 1904. A catalogue of the shore fishes collected by the steamer Albatross about the Hawaiian Islands in 1902. U.S. Fish Commission Bulletin: 513-538.

Spennemann, D.H.R. 1998. Excessive exploitation of Central Pacific seabird populations at the turn of the 20th century. Marine Ornithology 26 (1-2): 49-57.

Summers, A.P., K.E. Hartel, and T.J. Koob. 1999. Agassiz, Garman, Albatross, and the collection of deep-sea fishes. Marine Fisheries Review 61: 58-68.

Thompson, G.B. 1948. Mallophaga collected by the Tanager Expedition. Bernice P. Bishop Museum Occasional Papers 19: 195-200.

Timmers, M.A., C.A. Kistner, and M.J. Donohue. 2005. Marine debris of the Northwestern Hawaiian Islands: ghost net identification. NOAA Coral Reef Ecosystem Division and University of Hawai'i Sea Grant Program Report: 28pp. 
Tissot, B.N., W.J. Walsh, and M.A. Hixon. 2009. Hawaiian Islands marine ecosystem case study: ecosystem- and community-based management in Hawaii. Coastal Management 37: 1-19.

Toonen, R., J. Leong, and C. Wiener. 2010. Hawai'i Institute of Marine Biology semi-annual report XII, University of Hawai‘i, Honolulu, Hawaii, USA, 2010.

Toonen, R.J., K.R. Andrews, I.B. Baums, C.E. Bird, G.T. Concepcion, T.S. Daly-Engel, J.A. Eble, A. Faucci, M.R. Gaither, M. Iacchei, J.B. Purits, J.K. Schultz, D.J. Skillings, M.A. Timmers, and B.B. Bowen. 2011a. Defining boundaries for ecosystem-based management: a multispecies case study of marine connectivity across the Hawaiian Archipelago. Journal of Marine Biology Special Issue: Ecosystem-Based Management of Pacific Islands. Article ID 460173, 13pp.

Toonen, R.J., J.D. Lemus, K. Selkoe, and B.S. Halpern (eds). 2011b. Ecosystem-Based Management of Pacific Islands. Special Issue Journal of Marine Biology. Hindawali Publishing Corp. Available online at www.hindawi.com/journals/jmb/psi/.

Treadwell, A.L. 1903. Polychaetous annelids of the Hawaiian Islands collected by the steamer Albatross in 1902. U.S. Fish Commission Bulletin (1903, Part III): 1145-1181.

Tsuda, R.T. 1965. Marine algae from Laysan Island with additional notes on the vascular flora. Atoll Research Bulletin 110: 38pp.

Vaughan, T.W. 1907. Recent Madreporaria of the Hawaiian Islands and Laysan. United States National Museum Bulletin 59: 625pp.

Vetter, E.W., C.R. Smith, and F.C. De Leo. 2010. Hawaiian hotspots: enhanced megafaunal abundance and diversity in submarine canyons on the oceanic islands of Hawai'i. Marine Ecology 31(1): 183199.

Vroom, P.S. and K.N. Page. 2006. Relative abundance of macroalgae (RAM) on Northwestern Hawaiian Island reefs. Atoll Research Bulletin 543: 533-548.

Vroom, P.S., K.N. Page, K.A. Peyton, and J.K. Kukea-Shultz. 2006. Marine algae of french Frigate Shoals, Northwestern Hawaiian Islands: species list and biogeographic comparisons. Pacific Science 60(1): 81-95.

Wagner, D., Y.P. Papastamatiou, R.K. Kosaki, K.A. Gleason, G.B. McFall, R.C. Boland, R.L. Pyle, and R.J. Toonen. 2011. New records of commercially valuable black corals (Cnidaria: Antipatharia) from the Northwestern Hawaiian Islands at mesophotic depths. Pacific Science: 65(2): 249-255.

Wagner, D., 'A. Wilhelm, A. Friedlander, A. Skeat, A. Sheppard, B. Bowen, C. Gaymar, C. Sheppard, G. San Martin, I. Wright, J. Philibotte, J. Parks, J. Bosanquet, J. Brider, K. Aiona, K. Morishige, L.

Wright-Koteka, N. Lewis, N. Brownie, R. Kosaki, R. Rotjan, J. Jamieson, R Toonen, R. Constantine, S. van Dijken, S. Anderson, S. Taei, T. Temata, T. Carruthers, T. Durbin, T. Teroroko, T. Short, W. Tooma, and Z. Basher. 2013. Big Ocean: a shared research agenda for large-scale marine protected areas. Big Ocean and Papahānaumokuākea Marine National Monument. Honolulu, HI: 21pp.

Waller, R.G., and A.R. Baco. 2007. Reproductive morphology of three species of deep-water precious corals from the Hawaiian Archipelago: Gerardia sp., Corallium secundum, and Corallium lauuense. Bulletin of Marine Science 81(3): 533-542.

Ward, H.E.M. 2010. Creating the Papahānaumokuākea Marine National Monument: disclosure, media, place-making and policy entrepreneurs. Ph.D. thesis. East Carolina University. 157pp.

Westervelt, W.D. 1916. Hawaiian legends of volcanoes (mythology) - collected and translated from the Hawaiian. Ellis. Boston, MA: 205pp.

Wiener, C.S., M.A.J. Rivera., R.J. Toonen, J.C. Leong, R.K. Kosaki, S. Karl, K. Keller, and H. Johnson. 2011. Creating effective partnerships in ecosystem based management: A culture of science and management. Journal of Marine Biology Special Issue: Ecosystem-Based Management of Pacific Islands: Article ID 241610, 8pp.

Wilhelm, A., S. Taei, and T. Teroroko. 2011. Big Ocean: A Network of the World's Large-Scale Marine Managed Areas. Second International Marine Conservation Congress. May 17, 2011. Victoria, Canada: 13pp.

Woodward, P. 1972. The natural history of Kure Atoll, Northwestern Hawaiian Islands. Atoll Research Bulletin 164: 318pp. 
Williams, I.D., B.L. Richards, S.A. Sandin, J.K. Baum, R.E. Schroeder, M.O. Nadon, B. Zgliczynski, P. Craig, J.L. McIlwain, and R.E. Brainard. 2011. Differences in reef fish assembalges between populated and remote reefs spanning multiple archipelagos across the Central and Western Pacific. Journal of Marine Biology Special Issue: Ecosystem-Based Management of Pacific Islands: Article ID 826234, 14pp.

Yamase, D.K. 1982. State-federal jurisdictional conflict over the internal waters and submerged lands of the Northwestern Hawaiian Islands. University of Hawai i Law Review 4: 139-180. 